\title{
Clinical study of ectopic pregnancy at tertiary care center in Haryana, India
}

\section{Sushila Chaudhary*, Meenakshi B. Chauhan, Anjali Gupta, Monika Dalal}

Department of Obstetrics and Gynecology, PGIMS, Rohtak, Haryana, India

Received: 08 May 2019

Accepted: 11 June 2019

\section{*Correspondence:}

Dr. Sushila Chaudhary,

E-mail: sushilachaudhary68@gmail.com

Copyright: ( the author(s), publisher and licensee Medip Academy. This is an open-access article distributed under the terms of the Creative Commons Attribution Non-Commercial License, which permits unrestricted non-commercial use, distribution, and reproduction in any medium, provided the original work is properly cited.

\begin{abstract}
Background: Ectopic pregnancy is a life threatening condition in the first trimester of pregnancy. Diagnosis can be done by clinical examination, serum $\beta$-HCG and ultrasonography. This retrospective study was done to know the incidence, risk factors, and management of ectopic pregnancy.

Methods: It was a retrospective study conducted on 75 patients of ectopic pregnancy admitted at tertiary care hospital in Haryana from February-2017 to January-2019. Data collected from record room and analysis done.

Results: Total deliveries were conducted were 5064. The incidence of ectopic pregnancy was $1.48 \%$, majority of the women were in the age group of 21-30 (68\%), multi-parous $(77.32 \%)$. The most common risk factor was abortion $33.33 \%$, f/b tubal ligation was $13.13 \%$, medical management of ectopic pregnancy done in $30.66 \%$, $8 \%$ were managed by laproscopically and $58.66 \%$ by laparotomy.

Conclusions: Safe sexual practices can reduce pelvic infections and ectopic pregnancy incidences. Early diagnosis before tubal rupture can reduce morbidity and mortality in ectopic pregnancy.
\end{abstract}

Keywords: Amenorrhoea, Ectopic pregnancy, Laproscopy, Medical management, Risk factors, Salpingectomy

\section{INTRODUCTION}

In an ectopic pregnancy, the fertilized ovum is implanted and developed outside the normal endometrial cavity. This is a life threatening condition in the first trimester of pregnancy and one of the commonest cause of maternal mortality in first trimester. ${ }^{1}$ In $97 \%$ cases, the fallopian tube is the site of implantation, other sites are ovarian, abdominal (primary and secondary), cervical, angular cornual and caesarean scar pregnancy. Various risk factors are associated with ectopic pregnancy like the history of pelvic inflammatory disease (PID), tubal ligation, contraceptive failure, infertility, intra uterine device (IUD) use, previous induced abortions, previous ectopic pregnancy, use of assisted reproductive techniques, smoking and multiple sexual partners. ${ }^{2}$
Diagnosis of ectopic pregnancy is done by history of amenorrhea, pain abdomen and bleeding per vagina (classic triad), fainting attack history and clinical examination showing cervical motion tenderness, adnexial mass, fullness in the Pouch of Douglas (POD) and investigations, which are serum $\beta$-HCG levels, high resolution ultrasonography and in doubtful cases by laparoscopy. Serial serum $\beta$-HCG levels are important in the diagnosis of ectopic pregnancy. ${ }^{3}$ The incidence of ectopic pregnancy are increasing nowadays due to better diagnostic facilities and increased awareness. Aim of this study is to determine the incidence of ectopic pregnancy and to identify the risk factors and management of ectopic pregnancy at a tertiary care hospital. 


\section{METHODS}

This was a retrospective study conducted in department of Obstetrics and Gynaecology of a tertiary care hospital in Haryana for a period of two years.

\section{Study population}

Case sheets of 75 patients of diagnosed ectopic pregnancy who were admitted in labour room and ward were collected from record room for a period from February 2017 to January 2019 and studied for various parameters.

\section{Inclusion criteria}

- All cases of diagnosed ectopic pregnancy were taken.

\section{Exclusion criteria}

- All intra-uterine pregnancy cases were excluded from study.

This was a retrospective study. Case sheets of all 75 patients of ectopic pregnancy were studied for various parameters like age, parity, risk factors for ectopic pregnancy, clinical presentation, symptoms, general condition at admission and investigations in form of urine for pregnancy test, ultrasonography findings, $\beta$-HCG report and mode of management in detail.

\section{Statistical analysis}

The data for all parameters were collected, tabulated, and frequency and percentage were analyzed by using Microsoft Excel.

\section{RESULTS}

A total of 75 patients of ectopic pregnancy were studied during study period from February-2017 to January2019. The total number of delivery recorded was 5064 cases. The incidence of ectopic pregnancy in our study was $1.48 \%$. Majority of women were in age group 21-30 $(68 \%)$ and multifarious $(77.32 \%)$. Mean age was $27.32 \pm 2$ years. Age of the youngest patient was 18 year while the oldest was 38 year. Maximum patients were G3 or more (Table 1 and 2).

Table 1: Age wise distribution of ectopic pregnancy cases.

\begin{tabular}{|lll|}
\hline Age in years & No. of cases (75) & Percentage (\%) \\
\hline $15-20$ & 09 & 12 \\
\hline $21-25$ & 24 & 32 \\
\hline $26-30$ & 27 & 36 \\
\hline $31-35$ & 08 & 10.66 \\
\hline $36-40$ & 07 & 9.33 \\
\hline
\end{tabular}

More than $90 \%$ women presented with amenorrhea and pain abdomen (94.66\% and $90.66 \%$ respectively), bleeding per vagina was present in around $65 \%$ women, nausea and vomiting were presented in $10.6 \%$ and $2.6 \%$, while $4 \%$ women presented with history of fainting attacks and abnormal uterine bleeding respectively (Table $3)$.

Table 2: Gravidity wise distribution of cases.

\begin{tabular}{|lll|}
\hline Gravidity & No. of cases (75) & Percentage (\%) \\
\hline G1 & 17 & 22.66 \\
\hline G2 & 23 & 30.66 \\
\hline$>$ G3 & 35 & 46.66 \\
\hline
\end{tabular}

Table 3: Distribution of cases according to clinical symptoms.

\begin{tabular}{|l|l|l|}
\hline Symptoms & $\begin{array}{l}\text { No. of } \\
\text { cases }\end{array}$ & Percentage (\%) \\
\hline Amenorrhea & 71 & 94.66 \\
\hline Pain abdomen & 68 & 90.66 \\
\hline Bleeding per vagina & 49 & 65 \\
\hline Nausea and vomiting & 08 & 10.66 \\
\hline History of fainting attack & 02 & 2.66 \\
\hline Shock & 12 & 16 \\
\hline Abnormal uterine bleeding & 03 & 4 \\
\hline
\end{tabular}

Table 4: Distribution of cases according to general conditions.

\begin{tabular}{|llc|}
\hline General condition & No. Of cases & Percentage (\%) \\
\hline Stable & 63 & 84 \\
\hline Shock & 12 & 16 \\
\hline
\end{tabular}

Table 5: Risk factors in Ectopic pregnancy.

\begin{tabular}{|lll|}
\hline Risk factors & No. of cases & Percentage (\%) \\
\hline Abortion & 25 & 33.33 \\
\hline Previous surgery & 05 & 6.66 \\
\hline PID & 05 & 6.66 \\
\hline Tubal ligation & 10 & 13.3 \\
\hline $\begin{array}{l}\text { Infertility treatment } \\
\text { history }\end{array}$ & 03 & 4 \\
\hline $\begin{array}{l}\text { Previous ectopic } \\
\text { pregnancy }\end{array}$ & 02 & 2.66 \\
\hline $\begin{array}{l}\text { Cu-T insertion } \\
\text { history }\end{array}$ & 07 & 9.33 \\
\hline
\end{tabular}

Note- no identifiable risk factor -18 (24\%)

Around $16 \%$ women presented with hemodynamically unstable condition (shock) and $84 \%$ women presented with stable general condition (Table 4). The most common risk factor was abortion $33.33 \%$ followed by tubal ligation $13.33 \%$, History of previous surgery and PID was present in $6.66 \%$ each, previous history of ectopic was present in $2.66 \%$ and $24 \%$ women had no identifiable risk factors except multiparity (Table 5). 
Urine for pregnancy test was positive in all women $(100 \%)$. The ultrasonography, $\beta-\mathrm{HCG}$ were used as a diagnostic aid in $58.66 \%$ and $44 \%$ women respectively, while the laparoscopic diagnosis was made in $8 \%$ case of ectopic pregnancy (Table 6).

Medical management of ectopic pregnancy was done in $30.66 \%$ cases, laparoscopy was performed in $8 \%$, whereas failed medical management in $2.66 \%$ combined with laparotomy and direct laparotomy in $58.66 \%$ women (Table 7) in the present study.

Table 6: Diagnosis of ectopic pregnancy.

\begin{tabular}{|lll|}
\hline $\begin{array}{l}\text { Diagnostic } \\
\text { modalities }\end{array}$ & No. of cases & Percentage (\%) \\
\hline $\begin{array}{l}\text { Clinical examination } \\
\text { and UPT }\end{array}$ & 75 & 100 \\
\hline B-HCG & 33 & 44 \\
\hline Ultrasonography & 44 & 58.66 \\
\hline Laparoscopy & 06 & 8 \\
\hline
\end{tabular}

UPT: Urine Pregnancy Test

Table 7: Management of ectopic pregnancy.

\begin{tabular}{|lll|}
\hline $\begin{array}{l}\text { Mode of } \\
\text { management }\end{array}$ & No. of cases & Percentage $(\%)$ \\
\hline Medical & 23 & 30.66 \\
\hline $\begin{array}{l}\text { Failed medical f/b } \\
\text { laprotomy }\end{array}$ & 02 & 2.66 \\
\hline Laproscopy & 06 & 8 \\
\hline Laprotomy & 44 & 58.66 \\
\hline
\end{tabular}

\section{DISCUSSION}

Ectopic pregnancy is a life threatening condition in the first trimester of pregnancy. Nowadays, the incidence of ectopic pregnancy is increasing due to better diagnostic facilities and increased awareness. In the present study, the incidence of ectopic pregnancy was recorded around $1.48 \%$, which is comparable to the incidence reported by Kokate H, Prasannajeet et al, (1.33\%). ${ }^{4}$ Whereas, the study by Prasanna B, Jhansi $\mathrm{CB}$ et al, reported the incidence of ectopic pregnancy at around $1.8 \% .^{5}$

Umbilical majority of women in the present study were in the age group $21-30$ years $(68 \%)$ comparable to the study of Gaddgi et al (70.2\%). ${ }^{6}$ This is because our patients got married at early age and completed their family and this age group correspond to maximum reproductive activity. In the present study, the multiparous women were $77.32 \%$, while the study of Swami MB et al, reported $64.71 \%$, because multiparous women in their study had multiple risk factors like history of PID and previous surgery. ${ }^{7}$ In the present study, $94.66 \%$ women presented with history of amenorrhea, $90.66 \%$ with pain abdomen and bleeding per vagina in $65 \%$. In the Padmaja et al, study, women presented with amenorrhea were $87.5 \%$, pain abdomen in $75 \%$, while a study by Tahima $\mathrm{S}$ et al women presented with amenorrhea in $93 \%$ cases, but the classical triad of amenorrhea, pain and bleeding was seen only in $40.3 \%$ cases. ${ }^{8,9}$ The risk factors associated with ectopic pregnancy in the present study were abortion in $33.33 \%$, tubal ligation in $13.33 \%$, history of PID and previous surgery $6.66 \%$ each, previous history of ectopic in $2.66 \%$ cases. Study of Behera A et al, reported association of abortion in $46.2 \%$ and tubal ligation in $24.7 \%$ cases of ectopic pregnancy. ${ }^{10}$ Tubal mucosal damage secondary to infection in abortion hampers the embryo transfer activity and causes ectopic pregnancy. Increased incidences of ectopic pregnancy with tubal ligation are because of the faulty technique, post-partum ligation and failure to achieve hemostasis. In a study by Soren et al, the PID was associated in $5.6 \%$ and previous history of ectopic pregnancy in $1.39 \%$ cases of ectopic pregnancy. ${ }^{11}$ Tubal involvement in any disease is almost always bilateral so chances of repeat ectopic pregnancy are increased. In our study the clinical diagnosis and urine for pregnancy test were done in all cases and found positive irrespective of period of amenorrhea. Serum $\beta$ HCG was done in $44 \%$ women of ectopic pregnancy. In the present study, $30.66 \%$ women were managed with medical method by giving single dose of injection of methotrexate. All the women with stable general condition, $\beta$-HCG less than $3500 \mathrm{IU} / \mathrm{L}$, and gestational sac diameter less than $4 \mathrm{~cm}$, no cardiac activity and no evidence of hemoperitonium were taken for medical management in $2.66 \%$ medical management failed and patient landed in laparotomy due to persistence of symptoms and hemodynamic alterations. Laparoscopic salpingectomy was done in $8 \%$ and laparotomy was done in $58.66 \%$ women. In a study by Suseela TL et al, the medical management was done in $2 \%$, laparoscopic management in $8 \%$ and laparotomy in $90 \%$ cases of ectopic pregnancy. ${ }^{12}$ Post-operative period was uneventful in all women who had undergone laparotomy and no mortality was reported in the present study.

\section{CONCLUSION}

Doppler Health education and safe sexual practices are necessary to reduce ectopic pregnancy as these decreases chances of pelvic infections. Increased clinical suspicion, early diagnosis and timely management before tubal rupture have reduced morbidity and mortality in ectopic pregnancy.

\section{Funding: No funding sources}

Conflict of interest: None declared

Ethical approval: The study was approved by the Institutional Ethics Committee

\section{REFERENCES}

1. Cunninghum FG, LevenoKJ, Bloom SL, Hauth JC, Rouse DJ, Spong CY, et al Obstetrics. $23^{\text {rd }}$ ed. New York: McGraw Hill; 2010:238-254.

2. Bhavna G, Pathania K, Jindal M, Vohra R, Ahmed M. Risk factors for ectopic pregnancy: a case control 
study in tertiary care center. J Dental Med Sci. 2014;13(3):23-7.

3. Home AW, Duncun WC, Critchley HO. The need for serum biomarker development for diagnosis and excluding tubal ectopic pregnancy. Acta Obstet Gynaecol Scand. 2010;89:299-301.

4. Kokate H, Prasannajeet, Kurude V, Ahire B. Clinical study of ectopic pregnancy at tertiary care center in Mumbai. Int J Recent Advances Multidisciplinary Res. 2017;4(1):2163-5.

5. Prasanna B, Jhansi CB, Swathi K, Shaik MV. A study on risk factors and clinical presentation of ectopic pregnancy in women attending a tertiary care center. Int Arch Integrated Med. 2016;3(1):90-6.

6. Gaddagi RA, Chandrashekhar AP. A clinical study of ectopic pregnancy. J Clin Diagno Res. 2012;6:867-9.

7. Swami MB, Sharma P, Tyagi M, Kuswaha R, Harit J. Clinical study of ectopic pregnancy. J Evolut Med Dent Sci. 2015;4(86):15057-62.

8. Padmaja A, Vijaya K, Suresh U, Karanam R. Analysis of 40 cases of ectopic pregnancy to know the changing trends in the etiology and management. J Evolut Med Dent Sci. 2018;17(11):06-11.
9. Tahima S, Daniel M, Solomon P. clinical analysis of ectopic pregnancies in a tertiary care center in Southern India: a six year retrospective study. J Clin Diagno Res. 2016;10(10):QC13-QC16.

10. Behera A, Ghadei R, Bal NR. A Clinical study of ectopic pregnancy in a tertiary care hospital. Int $\mathbf{J}$ Reprod Contrcept Obstet Gynecol. 2018;7(11):446164.

11. Soren M, Patnaik R, Sarangi KB. A clinical study on ectopic pregnancy. Int $\mathrm{J}$ Res Med Sci. 2017;5(11):4776-82.

12. Suseela LT, Gunakala CK. A study on management, morbidity and mortality of ectopic pregnancy attending a tertiary care center at Rajiv Gandhi Institute of Medical Sciences General Hospital, Kadapa, Andhra Pradesh, India. Int J Reprod Contracept Obstet Gynecol. 2016;5(11):3736-9.

Cite this article as: Chaudhary $\mathrm{S}$, Chauhan $\mathrm{MB}$, Gupta A, Dalal M. Clinical study of ectopic pregnancy at tertiary care center in Haryana, India. Int J Reprod Contracept Obstet Gynecol 2019;8:2816-9. 